\title{
Catherine of Siena's spirituality of political engagement
}

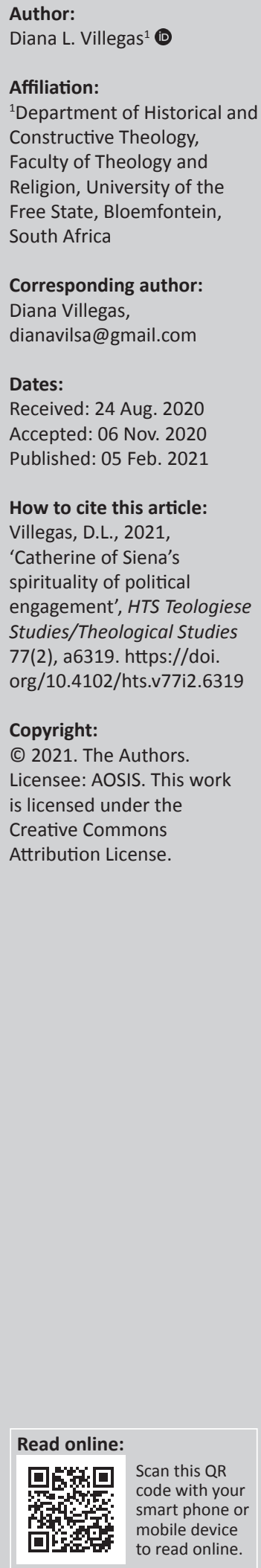

Well known as a mystic, Catherine of Siena has been credited with pope Gregory XI's return to Rome from Avignon, with convincing him to pursue a crusade and with playing a major role in making peace between the Papal League and Italian City states. This narrative ascribes these accomplishments to Catherine's extraordinary gifts, a fruit of her mystical experience. Contemporary historical research, however, shows that Catherine was chosen by ecclesiastical authorities to advocate for papal policies. She was guided to causes and policies she should pursue, which were already determined by the pope and his advisors. In light of this historical research and from the perspective of Christian spirituality studies, I examined Catherine's letters to pope Gregory XI to analyse and interpret her spirituality of political engagement. Her multiple authoritative exhortations to Gregory XI telling him how her wisdom applied to the choices before him can be read as a spirituality of papal governance and as 'formation' for his critical leadership of the church. By means of this article I have shown that Catherine's advice was intended for the salvation and transformation of others and for the good of the church so that it might best mediate salvation. This goal was her interpretation of the mission entrusted to her through her spiritual advisor. Her own spirituality in daring to forcefully 'form' the pope and in espousing papal causes by preaching her creative integration of Gospel wisdom was witness to an unselfconscious courage and utter trust in God acting through her; a fruit of her own profound journey of transformation.

Contribution: This article offers a new interpretation of Catherine of Siena's engagement in papal politics and related spirituality. Catherine was chosen for this task by ecclesiastical authorities, then construed this mission as a call to 'form' the pope; thus, her letters to Gregory $\mathrm{XI}$ are interpreted as a spirituality of papal governance.

Keywords: Catherine of Siena; Catherine of Siena politician; spirituality and politics; Gregory $\mathrm{XI}$ and Catherine of Siena; incarnational spirituality; women mystics political prophets; Raymond of Capua.

\section{Introduction}

Do Catherine of Siena's letters to Pope Gregory XI reveal a mystic who was also a politician? Scholars from multiple disciplines (History, Theology, Spirituality, Medieval Women Mystics and Literature) concur that Catherine was a mystic, but there are varied interpretations about her role as politician. The traditional view of Catherine credits her with persuading the pope to return to Rome and with making a major contribution to starting a crusade. She has been seen as a significant contributor to peace between the Papal League and the Italian City States. From the faith perspective this traditional narrative ascribes these extraordinary acts of an uneducated lay person to her holiness and, therefore, to God's power acting through her.

In this article from the perspective of Christian spirituality studies, I argue that Catherine's significance in terms of her engagement in ecclesiastical politics lies in her formulation of a spirituality of papal governance and her attempts to form the pope accordingly and in her witness to an incarnational spirituality even as she was, indeed, a mystic. Recent historical studies show that Catherine did not initiate her engagement in ecclesiastical politics, and she did not contribute significantly to the accomplishment of the causes in which she became involved. Accordingly, her significance does not lie in her achievements as an initiator or mover of major medieval ecclesiastical policies. These are not the signs of her extraordinary union with God. Rather, the fruit of her closeness to God was her faith and trust in God's power acting in and through her such that she readily addressed people at the highest levels of temporal and ecclesiastical power to communicate her exceptional wisdom. Catherine's role was akin to that of the Old Testament prophets called to present God's values to those in power. In 14th century Italy, ecclesiastical power and authority overlapped with temporal power and authority and Catherine was engaged in politics, but her motivation and significant contribution were of a religious nature. 


\section{Portrayals of Catherine as a politician}

There are a range of ways in which Catherine's engagement in ecclesiastical politics has been portrayed. ${ }^{1}$ The most influential and lasting portrayal of this involvement originated in the hagiographical works written to promote her canonisation by Raymond of Capua, ${ }^{2}$ her spiritual advisor and by Bartolomeo Dominici, a Sienese Dominican friar and close friend of Catherine's, who made major contributions to the Processo castellano, a dossier used to promote her canonisation (Processo 2009). Both implied that because of her spiritual gifts and the power of the Holy Spirit acting in her, Catherine influenced the calling of the crusade; Dominici suggested that she was majorly responsible for Pope Gregory XI's return to Rome. ${ }^{3}$ Both implied that Catherine initiated these causes.

Beginning with the hagiographies just mentioned, Catherine has been traditionally credited - to a greater or lesser extent - with strategising about how to accomplish papal policies or even initiating such strategies. She has been credited with a significant contribution to their execution. Today scholars have a variety of views. In his influential work on Catherine, medieval historian Thomas Luongo portrays her as politically astute and intentional in attempting to attain political goals. He argues that she was able to exercise political authority and take political initiatives as a result of the historical/ cultural context of her day, and not as much as a result of unique spiritual gifts. ${ }^{4}$ At the same time, Luongo documents the influence of others on her political engagements. André Vauchez, a major medieval historian who has done extensive work on Catherine, recognises the extent to which she was guided and advised by others, nevertheless he ascribes political agency to Catherine herself. For instance, he states that Catherine sent Raymond of Capua to Avignon (Vauchez 2018:50), when this trip was envisioned by Florentine and ecclesiastical leaders together with Raymond. ${ }^{5}$ Karen Scott, a historian with a different perspective, describes Catherine as an itinerant preacher and apostle seeking to promote peace based on religious values rather than social or political commitments (Scott 1992) and as having a profound desire to affect ecclesiastical reform and bring about peace based

1.In (2012) Thomas Luongo gave an account of the way Catherine's involvement in ecclesiastical politics has been interpreted over history.

2.Raymond describes her involvement in the calling of a crusade (Raymond of Capua 1980:section 291), although in line with late medieval views about sanctity, he focused on Catherine's holiness and extraordinary gifts and only schematically on her public life.

3.André Vauchez, a medieval and Catherinian historian asserts that Catherine's reputation for motivating the pope's return to Rome was most influenced by Dominici's work.

4.Luongo summarises these positions in the introduction to his book (Luongo 2006:1-22, especially 7; See also Luongo 2012).

5.Catherine's trip to Avignon was conceived by Florentine Guelph (pro-Papal League) leaders with Raymond's cooperation (Luongo 2006:169-173). As a female mystic Catherine would obtain a hearing from Gregory XI in order to open the door to a peace negotiation between Florence and the papacy. Raymond describes the plan: they [the Florentines] were compelled to treat for peace with the Sovereign Pontiff,
through the means of persons who they knew were acceptable to him. They were through the means of persons who they knew were acceptable to him. They were
informed that the holy virgin, by reason of the fame of her sanctity, was most informed that the holy virgin, by reason of the fame of her sanctity, was most
pleasing in the Pope's sight. Therefore, they ordained that I should first go to the pleasing in the Pope's sight. Therefore, they ordained that I should first go to the said Sovereign Pontiff in the name of Catherine in order to mitigate his indignation Cited in (Gardner 1907:161-162) [This older history is still considered an importan source, see Luongo 2012:26] on the desire for God's glory (Scott 1993). While viewing Catherine's motivation as religious, Scott credits her with political agency.

Of those who write from a theological or spirituality perspective, Giuliana Cavallini, the editor of the critical text of The Dialogue, (1995) and a major Catherine scholar and expert, depicts her as being active politically in order to seek justice and truth out of her 'love for all mankind [which] made her alert to the threats to common welfare all over Europe and caused her appeals to the rulers of European states' (Cavallini 1998:125). She was able 'to go back to causes of the general disease, to think of remedies, and to propose them to authorities' (Cavallini 1998:109). Suzanne Noffke who devoted her life to Catherinian scholarship and is the author of the most significant English translations of all of Catherine's work, asserts: 'her [Catherine's] interest was never in politics as such; in fact, she was and remained quite naïve regarding political complexities. Her single focus was the mission of the Church and its members' (Noffke 1996:55).

It is beyond the scope of this article to describe in detail and respond to these and other important portrayals of Catherine as a politician. I will focus on presenting my portrayal of Catherine's engagement in ecclesiastical politics first by describing recent historical research that leads to new interpretations of her engagement. I then present a detailed textual analysis of the original language texts of Catherine's letters to Gregory XI. Finally, I offer my interpretation of Catherine's involvement in ecclesiastical politics based on this analysis in dialogue with the historical research. To the best of my knowledge there is no other work that has explored the political dimensions of her spirituality in this manner.

\section{Historical context Raymond of Capua's influence}

Perhaps most significant for my interpretation of Catherine's spirituality of political engagement is historical research showing that her involvement in papal politics was initiated and guided by Raymond of Capua, her spiritual advisor, and by others involved in papal politics at a high level. ${ }^{6}$ Raymond, a well-educated, well-connected Dominican priest was chosen by ecclesiastical authorities to carry out a plan that would embark Catherine on a ministry as a holy woman mystic supporting papal initiatives (Coakley 2006:171-174; Luongo 2006:69-71). This plan was based on a medieval tradition about women mystics. Assumed to have prophetic insight as a result of their extraordinary relationship with God, they were sought by those in power for assurance from God regarding their policies or to offer inspired insight regarding their well-being or actions to be taken. Gregory XI had relied on Birgitta of Sweden and her visions to offer such guidance and reassurance. After she died in 1373 Gregory XI

6.Luongo summarises, "Catherine's travels and writing campaign were an organized and systematic effort by the supporters of the papal cause in Italy to enlist her saintly reputation and rhetorical skills for that cause' (Luongo 2006:89). See also saintly reputation and rhetorical skills for that cause' (Luongo 2006:89). See also
Coakley (2006:171-179), Luongo (2006:69-71), Vauchez (2018:50), and Beattie (2011:78). 
sought to replace her, and Catherine was recommended to him (See Gardner 1907:111; Luongo 2006:57; Vauchez 2018:32, 37, 51). Gregory XI did, indeed, ask for Catherine's prayers,? but is reported to have been disappointed by her as a prophetic visionary. Vauchez asserts that Catherine obtained only one interview with the Pope once she reached Avignon because, amongst other things, Gregory XI was 'disappointed that she did not transmit to him any sort of revelation given to her by God concerning his return [to Rome]' (Vauchez 2018:51). Similarly, Luongo summarises: 'Catherine is a prophetess or a mystic who through her extreme asceticism has been granted intimacy with Christ. Thus, what Gregory wants from Catherine is not her advice but access through her to divine wisdom' (Luongo 2012:24).

Raymond himself explained in writing that he was assigned to Catherine 'for the saving of souls, the Crusade, and other business of the Holy Roman Church' (Cited in Luongo 2006:70). In three letters related to the crusade, Catherine describes that Raymond received a request from the pope to enlist Tuscan citizens to support or participate in this endeavour (Letters 133, 131 and 144). Her letters and travel advocating for the crusade followed upon this papal request to highly placed authorities in Tuscany. Another example of Raymond's direct influence is her letter to the pope's secretary, Nicola da Osimo, where Catherine recommends that the pope appoint a particular Dominican as General of the order (Letter 181). Florentine leaders together with Raymond planned Catherine's trip to Avignon based on their belief that the pope would listen to her as a female mystic (in contrast to a politically involved man). ${ }^{8}$ Indeed, it is clear from the letters Catherine wrote and the trips she made to advocate on behalf of the pope that Raymond and his ecclesiastical circle considered a holy female mystic as someone who might be particularly persuasive with temporal and ecclesiastical leaders in advocating for the pope's policies and directed her to the appropriate contacts. Luongo tells us, 'Evidently, Catherine was being employed by the church party to help maintain Pisan and Luccan neutrality, a conclusion suggested by one of her letters to some female followers in Siena' (2006:161). ${ }^{9}$ Vauchez cites documents in which Gregory XI explicitly says that he wants Catherine sent to Florence to negotiate because, 'the Florentines will not dare attack Catherine, because she is a woman and they venerate her' (Cited in 2018:56).

Catherine was an uneducated young woman, the 24th child of a wool merchant's family. She would have had no education or context in her own home to form opinions or judgements regarding papal politics (although older brothers

7.In Letter 233 , she tells Gregory that she has prayed as requested by Raymond about his return to Rome. 'I prayed before and after communion. I saw no danger'. And in Letter 238 Catherine responds to Gregory XI's requests that she pray for his plans to return to Rome.

8.See note 5 . 9.At the end of her life Catherine became involved in the cause of advocating for
Urban VI against the new Avignon pope. I found less historical evidence to analyse the extent of Catherine's own initiative in this advocacy. It may be that by this time in her life she did, in fact, take more unguided initiatives, although we know in her life she did, in fact, take more unguided initiatives, although we know
Raymond was also deeply involved in Urban VI's cause. While he no longer lived Raymond was also deeply involved in Urban Vl's cause. While he
close to Catherine he continued frequent communication with her. were involved in local politics). It follows that her opinions regarding ecclesiastical policies were formed by Raymond and the circle of powerful church and temporal leaders with whom she became connected not only through Raymond but also before him through the Dominicans of Siena and temporal leaders from that community. ${ }^{10}$

\section{Catherine's political causes: Innovation and success?}

The policies that Catherine advocated were not innovative rather they were policies that Gregory XI and highly placed pro-Papal League authorities wished to pursue. Several historians concur that Gregory XI had been trying to get a crusade underway since he was elected pope in 1371, well before Catherine became involved in $1374 .{ }^{11}$ The pope's return to Rome had been an issue of papal politics prior to Gregory XI's election, and he was interested in returning to Rome from the start of his papacy. ${ }^{12}$ Raymond and leaders in the Guelph (pro Papal League) parties involved her in the power struggles between the Papal League and City States and coached her on acting as mediator for the Papal League's strategies. For instance, she was coached to engage on behalf of the Pope's policies with Pisa, Lucca, Florence and Siena and with and Bernabò Visconti of Milan who tried to organise opposition to the pope..$^{13}$ As already mentioned, she went to Florence as emissary for the pope because he thought as holy woman she would be well received and so Catherine was coached to act on the pope's behalf.

Catherine's advocacy for the causes in which she engaged was not particularly valuable to their achievement. Gregory's efforts to promote a crusade was an ill-timed effort that eventually failed. ${ }^{14}$ Catherine's involvement in peace-making between the City Sates and the pope was complex, but ultimately peace did not depend on Catherine's actions. ${ }^{15}$ The pro-Papal League civil authorities who advised her were only partially successful and were not on the 'right side' of history in that they opposed those calling for Italian, local political identity and rejection of political authority by foreign papal representatives (see Luongo 2006:167-168). Despite her efforts, Catherine had a marginal, if any influence, on accelerating the pope's plans to return to Rome, which

10.Vauchez and Luongo both document how Catherine moved amongst political and civic leaders in Siena as a result of her connection with the Dominicans (Luongo 2006:66; Vauchez 2018:28-29). Through Raymond and these connections she was 2006:66; Vauchez 2018:28-29). Through Raymond and these connections she was
also introduced to the highly placed persons in the cities to which she travelled.

11.For a history of Gregory and the crusade, see Thiebault (1985).

12.'Today it is well established that it was not Catherine's intervention that prompted Gregory XI to leave Avignon for Rome on September 13, 1376. The pope indeed seems to have made the decision in his heart not long after his election' (Vauchez 2018:51). See also Luongo (2006:58).

13.Luongo's book devotes two chapters to Catherine's involvement in Tuscan and Papal League politics. See chaps. 2 and 5 (Luongo 2006).

14.Gregory XI attempted to organise a crusade from the time of his election in 1371 but failed in convening one. Even the contingent of Hospitallers he sent to the Balkans shortly before his death failed in their efforts. See Thiebault (1985).

15.See Vauchez (2018:52), Beattie $(2011: 86,97)$. Noffke states that peace with Florence was 'accomplished almost in spite of her' (2000-2008:vol. III, 169). Catherine's involvement with Florence in particular left her more than once on the losing side of the struggle as in the refusal of Florentine envoys to use her as a losing side of the struggle as in the refusal of Florentine envoys to use her as a
mediator in Avignon and her persecution by the Ghibelline side during a 1378 mission to Florence (Luongo 2006:197-201; Vauchez 2018:51). 
was short-lived (14 months) and after his death the election of Urban VI led to the Great Schism and 39 years of a split papacy. ${ }^{16}$

In short, these historical data show us that Catherine did not herself initiate involvement in ecclesiastical policies that the policies she advocated were not innovative or hers, and that the persons with ecclesial and temporal power with whom she spoke and to whom she wrote were introduced to her by Raymond and other politically engaged persons in her entourage. ${ }^{17}$ We saw that Catherine's engagement was neither significant in the achievement of the Pope's return to Rome, the pursuit of a crusade nor was it significant in achievement of peace between the City States and the Papacy. These historical realities belie assertions made in accounts of Catherine's life beginning with her hagiographers. Accordingly, her significance in terms of these involvements, lies elsewhere, as we shall see in her letters.

\section{Letters to Gregory XI}

Catherine wrote 14 letters to Gregory XI between 1375 and his death in $1378 .^{18}$ The urgency of peace is a topic of 11 letters $(185,196,206,209,218,229,239,252,255,270,285)$ in which Catherine pleads with Gregory to make peace with the Italian City States. Nine letters allude to the launching of a crusade $(185,196,206,218,229,238,239,252,255)$, a topic closely tied with making peace. Urging Gregory to return to Rome appears in seven letters $(185,206,229,231$, $233,238,239)$ and in eight, she addresses the importance of reforming the church by appointing to high ecclesiastical office clerics leading ordered lives $(185,196,206,209,238$, $239,285,270)$. While Catherine devotes most space to the topic of peace, we shall see that for her these topics are all intertwined. ${ }^{19}$

\section{Oral, exhortatory rhetoric}

Interpretation of Catherine's letters is based on textual analysis of an oral, exhortatory rhetoric. Catherine was not educated; she probably learned to read as an adult and perhaps write in the last years of her life. What she knew regarding the Christian faith she learned through listening to preaching and recitation of scriptures during celebration of the Hours or during Mass and from dialogue with her spiritual advisors, learned Dominicans and other welleducated clergy. She internalised and integrated this mostly oral knowledge through her many hours of prayer. She is

16. Beattie summarises: "Catherine's place in the papal politics of her time lies somewhere along the broad spectrum between the largely symbolic and the determinative. She was prominent and influential, but she neither drove events nor determined their trajectory' (2011:97).

17.Catherine wrote about ecclesiastical politics to many not in power, including he followers and spiritual advisors. Undoubtedly, these contacts were initiated by her.

18.Letters, 185, 196, 206, 209, 218, 229, 231, 233, 238, 239, 252, 255, 270, 285.

19.Catherine wrote many letters to ecclesiastical and temporal leaders regarding the crusade, the pope's return to Rome and the conflict between the papacy and the City States. Ilimit myself to an analysis of the letters to Gregory XI for severa reasons. Grefor is at the centre of these policies. Catherine's arguments are repeated in different forms in all her letters related to these topics. Most of all, it would be impossible to cover all her letters and present a detailed, textual analysis in one article. described by those close to her and, significantly, by historical chroniclers who experienced her, as being naturally intelligent and capable of excellent communication (Vauchez 2018:57). This excellent communication included the unique rhetorical style preserved in her letters, which were dictated to scribes, and therefore a form of oral transmission..$^{20}$ As we shall see here, her rhetoric was passionate; it was filled with overlapping metaphors and repetitions. Her letters are exhortations often interrupted with prayers directly to God. As in sermons or poems Catherine's metaphorical communication offers layers of meaning rather than sequential logic.

\section{Pope's role and authority}

Catherine's beliefs about the pope's role, based on ecclesiology of her day, gave urgency to the formative role she assumed when she became engaged in his causes. The pope is father as God is father, that is, the ultimate, although loving and merciful authority on earth. This authority has been given by God and must be used for the good of the church. Most significantly, although, the pope is a mediator of salvation, he is Christ on earth. ${ }^{21}$ Indeed, Catherine commandingly tells Gregory that she speaks in the name of Christ in asserting that his authority is so sacred and important for the church that if he does not use it for good he should give it up, if nothing else, for his own salvation:

As God gave you authority, and you have taken it up, you must use your power and virtue; for if you should not chose to use it, it would be better to give it up for the greater honour of God and the salvation of your soul. (Letter 255) ${ }^{22}$

Catherine uses multiple metaphors to drive home to Gregory XI the significance of his role, which must be rooted in love. She affirms '[You are] the sweet true shepherd, learning from Christ the shepherd whose place you take' (Letter 218). As did Jesus, Gregory should devote his life to the care of his sheep and even be willing to give his life for their well-being; this should be the case even if some of the sheep have betrayed him as Jesus was betrayed by his apostles. Through his authority and role as shepherd who gives his life for his sheep, the pope is mediator of salvation (Letter 218). The pope is like Peter who has the keys to mediate between heaven and earth. 'You have in your hands the keys to Heaven' she tells him. (Letter 255) The pope is also the doorkeeper of the blood of the lamb. She tells him:

Oh! shepherd and doorkeeper of the blood of the lamb. ... You are the doorkeeper of God's wine cellar, that is of the blood of the only Son, whom you represent on earth; Christ's blood can be made available through no other hands but yours', (Letter 270)

20.For a more detailed and documented discussion of Catherine's education, formation and style of communication, see Villegas (2013). See Tylus $(2009,2012$ for a detailed literary discussion of Catherine's letters, their oral nature and their place in Italian literature.

21.For instance, 'I say to you, sweet Christ on earth, on behalf of Christ in heaven'. (Letter 196) 'The Holy Father, our Christ on earth, wants to know the disposition and will ...' (Letter 131).

22.Translations are my own based on the latest critical edition of Catherine's letters (Catherine of Siena 2002). Letter numbering corresponds to T (Tommaseo) numbering in Noffke's English translations unless otherwise noted; see index in vol. 4 as letters are published in historical, not numerical order (Catherine of Siena 4 as letters are
2000-2008). 
[And] Now you can act as minister of the blood of the Lamb. $(\text { Letter 239 })^{23}$

Interestingly, the pope is not only the father, but also the mother in offering the nutrition of grace (salvation). Catherine tells Gregory: 'you are that mother who nourishes us at the breast of divine charity'; she then shifts within the same stream of thought to the metaphor of the blood as the fluid of salvation. 'You do not offer us blood without fire, nor fire without blood, because the blood was dispensed with the fire of love' (two forgoing citations, Letter 270). The pope as mother conveys not only the foundational role of the pope in mediating salvation (offering transforming love, the fluid of the blood, Jesus very life), but is, with the metaphor of shepherd, an expression of the loving nature of the pope's authority.

As part of his salvific function, the pope has power to bring order in the church as an institution in a manner that makes salvation possible; he can call and organise a crusade, he can and must appoint virtuous church leaders (Letter 218). That the pope is a mediator of salvation is inherent in his role and is the case irrespective of his personal qualities or his degree of holiness. Catherine enunciates her belief that the mediation of salvation by the pope, and mediation of grace through the sacraments by priests, is never invalidated by their lack of personal holiness. ${ }^{24}$ Accordingly, she is not deterred by knowledge of any of Gregory's weakness or sins in her exhortation that he performs his central role as a mediator of grace and salvation.

In short, the pope's life must be guided by the sacredness of the roles entrusted to him by God. Most crucially, these sacred roles must inform all policies and choices for they determine the eternal well-being of all Christians and even the 'unbelievers', ${ }^{25}$ as we shall see here.

\section{Peace}

'Peace, peace, peace, my sweet father, no more war!' (Letter 218); Catherine exclaims to Gregory in one of her letters. This passionate insistence on peace appears in most letters because, for Catherine, peace is essential to salvation and the well-being of the church. She told Gregory that it was his duty to recover persons for whom Christ shed his blood rather than try to recover cities for the papacy. She insisted that if Gregory chose souls instead of cities he would eventually get both (Letter 209). In the absence of peace, political leaders, clergy and ordinary citizens in rebellious cities, or anyone fighting against the Papal League (such as

23.In Catherine's letters and her main work, The Dialogue (Catherine of Siena 1980) blood is a frequent multifaceted metaphor for salvation, for grace, for Christ's dying for us, for Christ's life and for the sacraments. For instance, from Dialogue section 115, God speaking to Catherine, 'Thus his blood and his death, by the power of my divine nature joined with his human nature, unlocked eternal life' [p. 214]. For an ode to Christ's blood beginning with 'Oh sweet blood that brings the dead to life ...' see Letter 295 to Raymond her spiritual director.

24.This theology and belief on Catherine's part can be found in detail in The Dialogue (especially sections 115-117) and multiple letters such as 191, 'if their [priests'] example should not reflect virtue, this would not diminish the life we receive from the sacraments'. See also Beattie (2011:79-80).

25.I use unbelievers throughout this article as it is the word used by Catherine to refer to the Muslim Turks. the Visconti in Milan) would be separated from salvation by not being in communion with the pope, the source of salvation. In addition, Catherine viewed rebellion against the pope, even for temporal reasons, as sinful. ${ }^{26}$ For instance, when Gregory XI prohibited the distribution of the sacraments in Florence to punish the city for its allegiance with Milan, Catherine chided those priests who eventually defied this prohibition and tried to minister to their parishioners. ${ }^{27}$

Given this interpretation of rebellion, Catherine insisted it was the pope's sacred job to make peace possible so that those rebelling would not be deprived of salvation. With her many dramatic metaphors and passionate rhetoric, Catherine attempted to shake the pope into realising this monumental responsibility and act accordingly. The pope must imitate Christ's mercy and be as that shepherd who welcomes the lost sheep, incurring in any suffering for the sake of the 'lost'. 'Carry the lost sheep on the shoulders of love and place her in the sheepfold of Holy Church' (Letter 229). As Christ on earth he must set his pride aside, his preoccupation with power or the bad advice of his curia and instead care for the good of the church when dealing with the City States, its leaders and clerics. The pope must bring back into the fold, 'your children who have rebelled against you, their father', to bring about reconciliation (Letter 218).

Gregory should keep in mind that when children are engaged in divisive conflict with their father, they are deprived of their inheritance, namely salvation. By remaining at war with his children (the City States and their leaders), the pope is depriving them of salvation. 'Ah! Father for love of God, so that so many children may not lose the inheritance of eternal life, that you know God has placed in your hands. ...' (Letter 218) she exhorts. She explicitly and forcefully urges him to make peace with Florence, 'God wants you [emphasis mine] to make peace with Tuscany', she tells Gregory XI (Letter 255; see also 229). The pope should also forgive the Sienese for their 'lapse' in joining the Florentines' against the Papal League (Letters 252, 285).

In several of her letters, Catherine explains the importance of making peace through merciful, parental love that offers reconciliation to a child who has misbehaved, and authoritatively tells the pope what he must do. The following passage is representative of many:

Ah my sweet holy Father! I see no other way or remedy to recover those sheep that left the fold of holy Church, those who are not subject to you, Father, nor obedient to you. I beg you in the name of Christ crucified, I want you [my emphasis] to offer this mercy, that with your goodness you defeat their malice. ... I demand mercy for them, Father, you must not take into account your children's ignorance and pride. Rather with the food of love

26.See Luongo's discussion on this $(2006: 168-169,86)$. See also Vauchez $(2018: 57)$. Gardner asserts, 'while admitting to the full that the iniquities and oppression of the papal officials were the real cause of the war, and that, humanly speaking, the rising of the cities of the States of the Church had ample justification, she regarded rebellion against the Pope as in itself a mortal $\sin ^{\prime}$ (1907:157).

27.See Letter 284 attacking priests who violated the Florence interdict and regretting how by doing so they not only sinned themselves but led the faithful into sin. 
and of your goodness, bring peace to us your miserable children who have offended you. I say to you, sweet Christ on earth, on behalf of Christ in heaven, [my emphases] that if you act in this way they will all return peacefully, pained by the offense caused to you and place their heads on your lap. And so you will rejoice and we will rejoice because with love you will have returned the lost sheep to the fold of holy Church. (Letter 196. See also Letters $196,209,218,229,255,285$ )

The sacred responsibility to mediate salvation should be pursued even if rebellious children have taken from the pope what is rightfully his (change of allegiance of City States previously in the Papal League, goods taken that belonged to the church, rebellion against interdicts). The implication in most letters to Gregory is that by virtue of his position as pope, he must not come across as an ecclesiastical politician or leader in the battle against others, but rather as a loving mediator of salvation:

Let us suppose that you have been greatly aggrieved, and what is yours has been taken away; nevertheless, Father, I beg you, do not take into account their malice and sin but your goodness, in order to mediate our salvation. Their salvation is that you make peace with them, for the child who is at war with the father, while at war is deprived of his inheritance. Oh my, Father, peace for the love of God, so that so many children will not lose the inheritance of eternal life, which you know God has placed in your hands. (Letter 218)

The pope is the Spouse of the church, so making peace amongst her children is the inherent duty in his role as husband. 'Holy Father, you should know that because you married holy Church, you committed to working for her' (Letter 252).

\section{Crusade}

A crusade was important for salvation of the crusaders and non-Christians. It was crucial for peace, and thus indirectly also for salvation. A crusade would foster peace by engaging professional soldiers and knights fighting on behalf of either the Papal States or the city states, keeping them from fighting each other. Catherine imagined mercenaries fighting 'unbelievers' in the Middle East, rather than fighting each other in Europe. 'I beg you to invite all who are rebelling against you to a holy peace, and so all warring will then fall upon the unbelievers' (Letter 185). The salvation of the crusaders would be facilitated both through obedience to the pope as crusaders rather than as mercenaries fighting against his causes and by engaging in a penitential journey (the crusade), which might also offer the possibility of dying for the faith. ${ }^{28}$ Not only would the salvation of former mercenaries, now crusaders, be ensured, but they would further contribute to the salvation of 'unbelievers'.

The peace for which Catherine advocated so passionately was amongst Christians. War became a holy endeavour when it was directed against 'unbelievers'. The criterion for war 28. For the traditional spirituality of crusade, which started in the 12 th century (see Flood 1974; Merton 2008). and peace is again, salvation. Thus, Catherine commandingly told Gregory that God wanted him to raise the standard of the cross in a holy war, 'raising high the cross' over the 'unbelievers' because this 'fiery, sweet cross' (citations Letter 218) can conquer the 'unbelievers' and recover them for the faith. She wanted Gregory to imagine how wonderful it would be if Christians could give the 'condiment of faith' to the 'unbelievers', who would then have God's light and with faith and light could journey to perfection. Gregory should further imagine the multiplier effect of conversion of the infidels. They would be like a 'new plant' that has received the warmth and light of the Holy Spirit, which would make it grow and produce fruits and flowers, that is virtue, that would benefit the mystical body of the church (Letter 218).

In the foregoing letter, Catherine advances an argument that does not seem to appear elsewhere, namely that converted infidels can contribute to the transformation and conversion of corrupt and sinful church leaders. As plants watered and nurtured by faith and God's light, the 'unbelievers' would counter the vices and moral disorder of church leaders, pastors, prelates and administrators, who are like the wolves who eat the sheep. She thus exhorts Gregory to find true shepherds, not wolves.

\section{Church leaders}

Catherine tells Gregory that it is particularly distressing to God that church leaders whose lives lack virtue, who live in princely wealth and in pursuit of prestige and power lead God's people astray by their example; for corrupt church leaders impair the salvation of others and the good of the mystical body of Christ - the church (Letter 270). Indeed, many lay persons shame these church leaders through their ordered, holy life (Letter 206). It is against the good of the church that those who care for the flock and distribute the church's resources to the poor should live in wealth and with the trappings of nobility. It is necessary for 'peace, God's honour and the salvation of persons' (Letter 206) that church leaders be persons capable of caring for the good of others, who live modest and virtuous lives. Catherine reports God's word to her:

I [God] want him [the pope] to raise the standard of the cross over those who graze and feed in the garden of Holy Church, the ministers of my blood, in order to persecute their defects and vices. [Then Catherine speaks directly to Gregory, reporting on what God wants] He wants you to take care that they are good and virtuous ... God does not want status, ranking or worldly trappings ... but only the riches of virtue. In this way those who are good and love the holy cross will persecute vice and those who are corrupt. (Letter 238)

The conversion of church leaders is essential not only for the well-being of the church, especially in terms of ministering to God's children, but it is also essential to peace. Catherine, authoritatively urges Gregory, 'if you asked me, "in what way can I bring peace about?" I would tell you, from Christ crucified [my emphasis] that you must do three things with 
your power' (Letter 206). Gregory should remove worldly leaders preoccupied with themselves rather than the good of the Church and its flock; he must return to Rome and he must bring about a crusade. With powerful metaphors Catherine admonishes:

In the garden of holy Church, you who are the manager of this garden, $[y o u]$ must remove the stinking flowers, full of garbage and cupidity, who are inflated with pride. These are the bad pastors and administrators that poison and rot the garden. ... Use your power and tear out these flowers, throw them out, that they should not govern. ... Plant in the garden sweet smelling flowers, pastors and administrators that are true servants of Jesus Christ, who are concerned only with the honour of God and the wellbeing of souls. (Letter 206)

In other words, the spiritual well-being of God's children depends on the virtue of the 'ministers of the blood'.

Catherine expresses a connection between peace and the purging of prelates who live disordered lives in a letter written after Gregory has returned to Italy. She points out that if he continues the wars with City States and territorial leaders, he will not be free to name pastors and church administrators according to their virtue and capacity to care for the good of the Church, which is ultimately the salvation of God's people, or as Catherine would say, saving souls:

Reform her [the church] with good pastors and administrators; you know you cannot do this with war; for thinking you have need of lords and princes, you will think you need to create pastors according to their requirements and not yours. Well, this is a terrible reason, that because of a perceived strategy one should place pastors or others in church leadership, rather than place those who are fully virtuous and who are persons who are not after their own self-interest, but rather pursue God's interest and the praise and glory of his name. ... Oh my! Do not act in this wrong way, for the sake of Christ crucified and the wellbeing of your soul! Remove any reason for war so that you are not led into the troublesome need to do their [corrupt church leaders'] will. (Letter 209)

\section{Return to Rome}

Catherine presses the pope to have courage, let go of fear and stop listening to his French Curia (Letters 231, 233) and hurry his return to Rome; for this is where he rightfully belongs as spouse of the church. The pope's 'legitimate children' are in Rome and not in France (Letter 239). It was her belief along with many theologians and canonists of her day that Rome was the rightful place for God's representative on earth (Letter 206). ${ }^{29}$ As we shall see, she also connects the return of the pope to Rome to her ultimate value, salvation. Catherine is so certain about this advice that she tells the pope that he is called to return to Rome in the name of Christ:

Respond to God who calls you and come, take possession of the seat of the glorious shepherd, St. Peter, for you are his vicar. Ah!

29.Catherine's own theology was simple: Peter resided in Rome, therefore, God wants the pope to reside in Rome. See Noffke's comments, (Catherine of Siena 2000-2008:II.63 note 12). Birgitta of Sweden had told Gregory that God wanted him to return to Rome and Catherine is likely to have known this (Catherine of Siena 1982:vol. I, 109). Vauchez tells us 'By the year 1370, the conviction that Rome was the centre of the Christian world was widespread in Italian civic circles' (Vauchez 2018:39). my sweet father, sweetly I beg you to come and defeat our enemies. I tell you this on the part of Christ crucified. (Letter 206)

Rightly or wrongly, she urges Gregory that his flock in Italy is waiting for him and needs him. ' Go on! Carry out the plan you made to come ... Please! Feed your hungry servants who are waiting for you at this time with deep and heartfelt desire' (Letter 218). She emphasises the urgency of his return with a vivid metaphor that highlights how his return is essential to the well-being of the church. 'Go quickly to your Bride who awaits you pale that you may instil some colour into her' (Letter 231).

From Catherine's perspective, if the pope is in Rome, the prized goal of peace with City States will happen more easily and quickly. Furthermore, the renewal of the church through the removal of corrupt clerics and the appointment of truly pastoral ones is more likely to occur.

\section{Spirituality of Papal governance}

The letters discussed above reveal that Catherine's primary intention in her communication with Gregory XI was to form him, to challenge him to live according to gospel values so that he could carry out his crucial responsibility for the salvation of persons. In the process Catherine articulates a Christian spirituality of papal governance.

Catherine's belief, borne of her theology, that the pope was mediator of salvation shaped the urgency, passion and perseverance with which she exhorted Gregory XI. Thus, all her letters included forceful advice to live the spiritual wisdom for which she is known. ${ }^{30}$ It was urgent that the pope engage in a journey of knowledge of God and self that would lead to transformation of the capacity for love and truth, transformation that would enable him to see and act upon the advice Catherine gives in her letters. Such conversion involved movement away from self-centred preoccupation towards capacity to care for the good of the other and went hand in hand with the increased ability to perceive the truth, that is, to see reality through lenses that are not self-centred. ${ }^{31}$ Such a spiritual journey would enable Gregory XI to make choices that mediated salvation for Christians and non-Christians no matter the cost to him, to his plans for temporal power and to his relationship to monarchs and curia members. Gregory XI would then be free to see that he must go to Rome, that he must make peace with the city states and do this through merciful, fatherly care and that he must call a crusade. Also, he would see that he must choose church leaders who were virtuous and capable of ministering out of lives of virtue.

If spirituality involves purposeful approaches to the living of life guided by beliefs deemed to address questions of meaning and to make possible greater wholeness and transcendence

30.Catherine was named doctor of the Catholic Church for her wisdom and her fresh and innovative interpretation of the gospel (Paul VI, October 4 1970).

31.Catherine's spirituality is summarised in a number of works (see McDermott 2008:78-137; Noffke 1996:11-37; Villegas 2017). 
(Villegas 2018:2), then a spirituality of papal governance would say something like the following. The pope is Christ on earth, the mediator of salvation and the head of the mystical body of Christ. Therefore, these core values must guide a purposeful approach to living life as pope. The pope must prioritise a life of knowledge of self and of God that allows the transformation necessary to act out of the responsibility inherent in these unique roles. $\mathrm{He}$ must be transformed enough to be able to weigh choices of ecclesiastical politics according to the guiding principle that he is the mediator of salvation. His life must be so converted that he is able to recognise the choices that best serve to live out and apply that value.

\section{Catherine's incarnational spirituality}

Catherine is known as a mystic. This characterisation, both in Christian and non-religious historical literature, refers most generally to someone who has exceptional spiritual experiences and gifts. From a Christian point of view, mysticism is most essentially characterised by the transforming experience of the presence of God. ${ }^{32}$ This experience is most authentic not because of extraordinary visions or experiences or because of exceptional insight into present and future realities; rather this experience is most authentic when it effects transformation into being a follower of Jesus, that is, someone capable of giving of self for the good of others. In some mystics, this self-giving might authentically be lived out through a life of intercession and asceticism as offering for the good of others.

In Catherine's case, she eventually felt called to engage with those around her rather than remain a contemplative hermit, and in due time, this call entailed working for the good of the church through advocacy with the most highly placed ecclesiastical and temporal authorities. In passionately and single-mindedly devoting herself to this task, in the authoritative way in which she sought to form Gregory XI, in her lack of self-consciousness and concern for what others might think of her, she witnessed utter faith and trust in God's power acting in her and through her. She was willing to engage with the educated and powerful and forcefully exhort them, unconcerned about her youth or being a woman and an uneducated lay woman at that. Unquestioning trust and faith in God are central to Jesus' call to his apostles and, therefore, a core Christian value to which Catherine witnessed in a timeless manner.

Thus, Catherine's greatness in terms of spirituality is her witness to the powerful transformation she lived, allowing her to act out of an utter trust in the presence of God acting in her and through her, responding to a call to engage with powerful leaders. Her greatness does not lie in coming up with policy ideas that she initiated or accomplished (such as bringing Gregory XI back to Rome), nor in encouraging the pope to pursue policies he and 32.This is the argument of the great historian of mysticism, Bernard McGinn. See, for example (1997:xvi-xx, 1998:25-29). others desired, although this was part of the call to which she responded. We saw that the papal policies she advocated were not particularly successful, including the pope's only too short return to Rome. In addition, from a 21st century perspective one can question some of her theology; for instance, that the pope must be obeyed no matter what, as in the case of the Florence interdict or her theology of a crusade.

Also, Catherine witnessed to another dimension of an incarnational spirituality, namely that God works in history through particular individuals and calls persons with unique qualities to certain ministries. Her experience of God and utter trust in God's action through her would not have been enough for Catherine to engage in the authoritative and forceful exhortation of the pope. From testimonies of contemporaries we know that she was intelligent and had an authoritative - if not an authoritarian streak to her personality. We saw in the given letters that she told the pope 'I want' and categorically spoke to him in the name of Christ. To this authoritative stance was added her gift for passionate, metaphor-rich rhetoric appreciated in her day. These personality characteristics empowered by her closeness to God undoubtedly made possible the bold effort to form the pope and persuade him and others to take certain actions. In other words, her unique personal qualities were necessary for her ministry of speaking God's word in history.

Finally, Catherine witnessed to the fact that no area of human endeavour is excluded from God's concern and, therefore, God's call to persons to speak God's word in history and for history. The timeless value here is that an extraordinary union with God can point someone to speak God's word in the political arena, to weigh in on policies of state at the highest level. Her spirituality of papal governance points to the fact that all public figures could benefit from a spirituality with the sort of principles Catherine outlined, where persons in power would do well to lead a life of transformation so they can see the common good with God's eyes and receive the grace to act on this vision.

\section{Acknowledgements Competing interests}

The author declares that she has no financial or personal relationship(s), which may have inappropriately influenced her in writing this article.

\section{Author's contribution}

I declare that I am the sole author of this research article.

\section{Ethical considerations}

The author confirms that ethical clearance was not needed/ required for the study. 


\section{Funding information}

The author received financial support for the publication of this article from the University of the Free State.

\section{Data availability}

Data sharing is not applicable to this article as no new data were created or analysed during this study.

\section{Disclaimer}

The views and opinions expressed in this article are those of the author only and do not reflect the policy or position of any affiliated institution.

\section{References}

Beattie, B., 2011, 'Catherine of Siena and the papacy', in C. Muessig, G. Ferzoco \& B. Kienzle (eds.), A companion to Catherine of Siena, pp. 73-98, Brill, Leiden.

Catherine of Siena, 1980, The dialogue, transl. and ed. S. Noffke, Paulist, New York, NY. Catherine of Siena, 1982, Epistolario de Santa Catalina de Siena: Espiritu y doctrina, transl. and ed., José Salvador y Conde, San Esteban, Salamanca.

Catherine of Siena, 1995, Il dialogo della divina provvidenza ovvero libro della divina dottrina, ed., G. Cavallini, Cantagalli, Siena.

Catherine of Siena, 2000-2008, The letters of Catherine of Siena, transl. and ed. S. Noffke, 4 vols., Arizona Center for Medieval and Renaissance Studies, Tempe, AZ.

Catherine of Siena, 2002, 'Le lettere di santa Caterina da Siena', A. Volpato (ed.), Santa Caterina da Siena: Opera omnia, CD-ROM, Provincia Romana dei Frat Predicatori, Pistoia.

Cavallini, G., 1998, Catherine of Siena, Chapman, London.

Centi, T.S., Belloni, A. \& Laurent, M.H. (eds.), 2009, II processo castellano: Santa Caterina da Siena nelle testimonianze al processo di canonizzazione di Venezia, Nerbini, Florence.

Coakley, J.W., 2006, Women, men, and spiritual power: Female saints and their male collaborators, Columbia University Press, New York, NY.

Flood, B., 1974, 'St Bernard's view of crusade', Cistercian Studies 9(1), 22-35.
Gardner, E.G., 1907, Saint Catherine of Siena, a study in the religion, literature, and history of the fourteenth century in Italy, J.M. Dent \& co., E.P. Dutton \& co. history of the fourteenth
London, New York, NY.

Luongo, F.T., 2006, The saintly politics of Catherine of Siena, Cornell University, Ithaca, NY.

Luongo, F.T., 2012, 'The historical reception of Catherine of Siena', in C. Muessig G. Ferzoco \& B. Kienzle (eds.), A companion to Catherine of Siena, pp. 23-45, Brill, Leiden.

McDermott, T., 2008, Catherine of Siena: Spiritual development in her life and teaching, Paulist, New York, NY.

McGinn, B., 1997, Foundations of Mysticism, The Presence of God: A History of Christian western mysticism, vol. 1, Crossroad, New York, NY.

McGinn, B., 1998, The flowering of Mysticism. The Presence of God: A History of western Christian mysticism, vol. 3, Crossroad, New York, NY.

Merton, T., 2008, 'From pilgrimage to crusade', Cithara 48, 5-21.

Noffke, S., 1996, Catherine of Siena: Vision through a distant eye, Liturgical Press, Collegeville, PA.

Paul VI, October 4, 1970. Mirabilis in ecclesia deus, Editrice Vaticana, Rome.

Raymond of Capua, 1980, The life of Catherine of Siena by Raymond of Capua, Glazier, Wilmington, $\mathrm{DE}$.

Scott, K., 1992, 'St Catherine of Siena, "apostola"', Church History 61, 34-46. https:// doi.org/10.2307/3168001

Scott, K., 1993, “"lo Caterina”: Ecclesiastic politics and oral culture in the letters of Catherine of Siena', in K. Cherewatuk \& U. Wiethaus (eds.), Dear sister: Medieval women and the epistolary genre, pp. 87-121, University of Pennsylvania Press, Philadelphia, PA.

Thiebault, P., 1985, 'Pope Gregory XI (1370-1378) and the crusade', Canadian Journal of History 20, 313-336. https://doi.org/10.3138/cjh.20.3.313

Tylus, J., 2009, Reclaiming Catherine of Siena: Literacy, literature, and the signs of others, University of Chicago, Chicago, IL.

Tylus, J., 2012, 'Mystical literacy: Writing and religious women in Late Medieval Italy', in C. Muessig, G. Ferzoco \& B.M. Kienzle (eds.), A companion to Catherine of Siena, pp. 155-183, Brill, Leiden.

Vauchez, A., 2018, Catherine of Siena: A life of passion and purpose, Paulist, Mahwah, $\mathrm{NJ}$

Villegas, D.L., 2013, 'Catherine of Siena's wisdom on discernment and her reception of scripture', Acta Theologica 32, 209-227. https://doi.org/10.4314/actat. v32i $2 \mathrm{~S} .12$

Villegas, D.L., 2017, 'Continuous prayer in Catherine of Siena', HTS Teologiese Studies/ Theological Studies 73(3), 1-18. https://doi.org/10.4102/hts.v73i3.4611

Villegas, D.L., 2018, 'Spirituality and belief: Implications for study and practice of Christian spirituality', HTS Teologiese Studies / Theological Studies 74(3), 1-8. https://doi.org/10.4102/hts.v74i3.5037 